PRÁVNE ROZPRAVY ON-SCREEN II. - Sekcia dejín a teórie štátu a práva

online vedecká konferencia - 13. november 2020

\title{
VZNIK HLUČÍNSKA AKO NÁSLEDOK PRIJATIA VERSAILLSKEJ
}

ZMLUVY

THE ESTABLISHMENT OF THE HLUČÍN REGION

AS A CONSEQUENCE OF ACCEPTANCE OF THE TREATY

OF VERSAILLES

Dominika Kováčová ${ }^{1}$

DOI: https://doi.org/10.24040/pros.13.11.2020.sdtsp.27-39

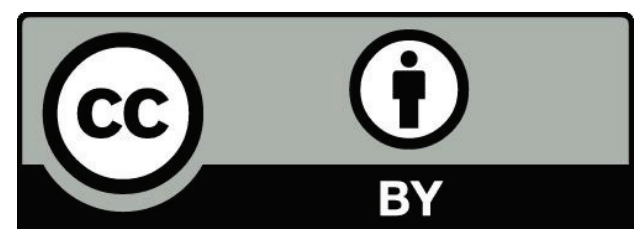

\begin{abstract}
Abstrakt
Po prvej svetovej vojne sa na strane vitazov ocitol aj novovzniknutý štát - Československo. Výsledkom mierových rokovaní v Pariži bolo prijatie piatich mierových zmlúv, vrátane Versaillskej zmluvy, upravujúcej vzt’ahy s Nemeckom. Úpravou hranic medzi Nemeckom a Československom (vo Versaillskej zmluve) sa k územiu Československa pripojilo Hlučinsko, spadajúce do oblasti Horného Sliezska. Prečo hovoríme o vzniku Hlučínska a ako sa vysporiadalo miestne obyvatel'stvo s daným stavom, bude predmetom nášho článku.
\end{abstract}

Kl’účové slová

Versaillská zmluva, Parížska mierová konferencia, Československo, Hlučínsko

\section{Abstract}

Czechoslovakia was one of the victorious states after the First World War. Five major peace treaties were prepared at the Paris Peace Conference, including Treaty of Versailles, which governed relations with Germany. The Treaty of Versailles regulated the borders between Germany and Czechoslovakia and Hlučin was annexed to Czechoslovakia. The subject of our article is the "establishment" of the Hlučin region and the behavior of the local population in this situation.

\section{Keywords}

Treaty of Versailles, Paris Peace Conference, Czechoslovakia, Hlučín region

\footnotetext{
${ }^{1}$ JUDr. Dominika Kováčová, Univerzita Pavla Jozefa Šafárika v Košiciach, Právnická fakulta, Katedra dejín štátu a práva, interný doktorand
} 


\section{PRÁVNE ROZPRAVY ON-SCREEN II. - Sekcia dejín a teórie štátu a práva}

online vedecká konferencia - 13. november 2020

\section{Úvod}

Právo národov na sebaurčenie predostrelo možnost’ na vytvorenie Československého štátu, sprevádzaného od svojho vzniku určitými problémami. Nejednotná právna úprava, štátne hranice ešte nevymedzené medzinárodnými zmluvami, československý národ brániaci novovzniknutý štát pred starými monarchiami, nespokojnost' príslušníkov nemeckej a mad’arskej národnosti žijúcich na území novej republiky, zotrvávanie mad’arských úradníkov na svojich postoch (predovšetkým na území Slovenska), nedostatok inteligencie z radov slovenského obyvatel'stva... S diametrálne odlišnými problémami sa musela vysporiadat' „vytvorená“ oblast'- Hlučínsko. Prijatím Versaillskej zmluvy sa pre jej obyvatel'stvo začala nová éra ked' sa po vyše sto rokoch, počas ktorých patrili pod územie Pruska, stali súčast'ou novovzniknutého štátu - Československa.

Versaillská zmluva bola prijatá 28. júna 1919. Bola výsledkom Parížskej mierovej konferencie, konajúcej sa bezprostredne po ukončení 1. svetovej vojny. Spolu s Versaillskou zmluvou boli prijaté aj zmluva zo Saint-Germain (zmluva s Rakúskom), zmluva z Neuilly (zmluva s Bulharskom), Trianonská zmluva (uzatvorená s Mad’arskom) a Sèvreská zmluva (uzatvorená s Osmanskou ríšou). Zmluvy boli v porovnaní s predchádzajúcimi mierovými zmluvami rozsiahlejšie, upravovali okrem iného aj vznik Spoločnosti národov a Medzinárodnej organizácie práce. Na Parížskej mierovej konferencii mala konečné rozhodnutia v kompetencii Najvyššia rada, ktorou bola sprvu Rada desiatich, neskôr už len Rada štyroch (Vel'ká štvorka). Vít’azné mocnosti, Vel'ká Británia, Francúzsko, Spojené štáty americké a Taliansko, tvorili vyššie spomínanú Vel'kú štvorku (v čase neprítomnosti talianskeho zástupcu sa zmenila na Vel'kú trojku). Najvyššia rada mala rozhodujúce slovo pri vymeriavaní vojenských, hospodárskych, morálnych sankcií a v neposlednom rade aj pri určovaní teritoriálnych zmien. S územnými požiadavkami po prvej svetovej vojne prichádzali nové národné štáty, odvolávajúce sa na Wilsonove princípy národného sebaurčenia. Rozhodnutia vít’azných mocností sa okrem iných snažila ovplyvnit' aj československá delegácia svojimi požiadavkami o územných nárokoch. 


\section{PRÁVNE ROZPRAVY ON-SCREEN II. - Sekcia dejín a teórie štátu a práva}

online vedecká konferencia - 13. november 2020

\section{Z ustanovení Versaillskej zmluvy}

Versaillská zmluva so svojimi 440 paragrafmi, rozdelených na 15 častí, bola recipovaná do právneho poriadku Československej republiky pod číslom 217/1921 Sb., ako „Mírová smlouva mezi mocnostmi spojenými i sdruženými a Německem a Protokol, podepsané ve Versailles dne 28. června 1919“. Dôležitými sa vo vzt’ahu k štátnym hraniciam Nemecka s Československou republikou stala Část II. - Hranice Německa a Č́st III. Politické klausule Evropské. Základné vymedzenie hraníc možno vyčítat' priamo z Versaillskej zmluvy: „Německé hranice budou stanoveny takto:... 6. S Československem: Hranice z 3. srpna 1914 mezi Německem a Rakouskem od svého styčného bodu s bývalou správni hranicí, oddělujici Čechy a Horni Rakousy, až k severnímu bodu výběžku bývalého rakouského Slezska, ležícímu asi 8 km východně od Prudníku (Neustadt)... “. ${ }^{2}$ Vzt'ah Nemecka a Československej republiky je d’alej stanovený v Části III. Oddíl VII., ktorý nesie názov „Stát československýc“. V ňom obsiahnuté články deklarujú uznanie úplnej nezávislosti Československého štátu a zároveň uznanie hraníc Československého štátu tak, ako boli určené Čelnými mocnost’ami spojenými a združenými a ostatnými zúčastnenými štátmi. Podl’a čl. 82 mala byt' hranicami medzi Nemeckom a Československým štátom určená na základe starej hranice medzi Rakúsko-Uhorskom a Nemeckou ríšou pred 3.augustom 1914. Na základe čl. 83 sa priamo geograficky vymedzili hranice ${ }^{3}$ a súčast’ou československého územia sa stala oblast' už označovaná ako Hlučínsko. Ako konštatuje jeden z múzejných pedagógov Múzea Hlučínska Jiří Nemínař, vznik Hlučínska bol do značnej miery len náhodný proces, ktorého celkový priebeh nie je doteraz známy. ${ }^{4} \mathrm{Na}$ základe ustanovení čl. 83 sa Nemecko vzdalo v prospech Československa všetkých práv a právnych titulov na čast' sliezskeho územia, vymedzeného nasledovne: Počínajúc od bodu položeného asi $2 \mathrm{~km}$ na juhovýchod od Ketře (Katscher), na hraniciach medzi krajom hlubčickým a ratibořským, hranicou medzi týmito dvoma krajmi, d’alej starou hranicou medzi Nemeckom a Rakúskom až k bodu ležiacemu na Odre priamo na juh od železnice Ratiboř-Bohumín a odtial' smerom na severozápad až k bodu ležiacemu asi 2 km na juhovýchod od Katře. Rovnako mala byt' na v zmysle ustanovení čl. 83

\footnotetext{
2 Č́st II. čl. 27 217/1921 Sb., ako „Mírová smlouva mezi mocnostmi spojenými i sdruženými a Německem a Protokol.

${ }^{3}$ Hranice v okresoch Ratiboř a Hlubčice sa určili jednoduchým zaznačením rovnej čiary na mape, ktorá oddelila čast' Pruska (súčast' Nemeckej ríše) a k Československej republike pripojila čast', ktorá sa odvtedy označuje ako Hlučínsko.

${ }^{4}$ NEMINÁŘ, J. : Československé územné nároky v Horním Slezsku. In: Hlučínsko. Vlastivědný časopis Muzea Hlučínska. roč. 10, 2020, č.1. s. 11
} 


\section{PRÁVNE ROZPRAVY ON-SCREEN II. - Sekcia dejín a teórie štátu a práva}

online vedecká konferencia - 13. november 2020

ustanovená komisia do 14 dní od nadobudnutia pôsobnosti Versaillskej zmluvy. Komisia mala určit' hraničnú čiaru medzi štátom Pol’ským a Československým na mieste samom. Zložená mala byt' zo siedmich zástupcov, z ktorých pät' malo byt' menovaných Čelnými mocnost'ami spojenými a združenými, jeden člen Pol'skom a jeden Československom a rozhodovat' mala väčšinovým princípom.

Dosiahnutiu územných ziskov obsiahnutých v ustanoveniach Versaillskej zmluvy predchádzali žiadosti a rokovania. Od vyhlásenia novej republiky sa Československo pripravovalo na Parížsku mierovú konferenciu. Vládnym nariadením č. 54/1918 Sb. z dňa 29. novembra 1918 sa zriadil koordinačný orgán nazývaný „Úřad pro přípravu mírové konference“ (d’alej len „Úrad“). ${ }^{5}$ Na základe ustanovení $§ 1$ pozostával Úrad z úradníkov menovaných predsedom ministerskej rady alebo ministerskou radou, ktorí sú k Úradu povolaní alebo prikázaní, a rovnako zo znalcov menovaných predsedom ministerstva. Hlavným poslaním Úradu bolo pripravit’ československú delegáciu, vzhl’adom na blížiacu sa konferenciu, voblasti poznania presných historický súvislostí, údajov, dát a máp. Československú delegáciu tvorili desiatky odborníkov a politikov a väčšina z nich pracovala pre Úrad.

\section{Územné nároky Československa v Memorande č. 8}

Rozhodnutiu prijat' obsah vyššie spomínaných článkov, majúcich vplyv na vytvorenie novej oblasti, predchádzali žiadosti a memorandá zo strany Československa. Edvard Beneš vystúpil 5. februára 1919 v trojhodinovom prejave pred Radou desiatich a predniesol požiadavky Československa. V následnej korešpondencii prezidentovi Československa- T.G. Masarykovi minister zahraničných vecí E. Beneš zhodnotil postoj Vel'kej Británie, Francúzska, Talianska a Spojených štátov amerických ako priaznivý, bez principiálnych námietok voči československému programu. ${ }^{6}$ Rada desiatich vytvorila komisiu, ktorá sa mala podrobne zaoberat' československou otázkou a podat' konkrétne návrhy. Komisii predložil E. Beneš písomne program, vo forme memoránd, obsahujúci rozšírený výklad požiadaviek,

\footnotetext{
${ }^{5}$ CHODĚJOVSKÝ, J. : Vědci uprostřed "velké politiky": pařř̌̌ská mírová jednání ve svědectví odborných poradců československé delegace. In: DEJMEK, Jindřich. Zrod nové Evropy: Versailles, St-Germain, Trianon a dotváření poválečného mírového systému. Praha: Historický ústav, 2011. s. 145

${ }^{6}$ IRMANOVÁ, E. : Mad'arsko a Trianonská mírová smlouva (pohled českého historika). In: Európa, nemzet, külpolitika, Tanulmányok Ádám Magda 85. születésnapjára. Budapešt’: Aura Kiadó. 2010. 100 s.
} 


\section{PRÁVNE ROZPRAVY ON-SCREEN II. - Sekcia dejín a teórie štátu a práva}

online vedecká konferencia - 13. november 2020

predtým prezentovaných Najvyššej rade. ${ }^{7}$ Memorandá, vo francúzskom jazyku sa používal termín mémoire, sa v českej literatúre označujú aj pojmom „pamětní spis“. Predložených memoránd bolo celkom jedenást' a významne prispeli $\mathrm{k}$ upevneniu a medzinárodnému uznaniu hraníc Československa. Jedným z najznámejších Benešových memoránd ${ }^{8}$ k Parížskej mierovej konferencii 1919/1920, v spojitosti s územím Hlučínska, ${ }^{9}$ je Memorandum č. 8. : České Horní Slezsko (Oblast Ratibořska). Originál memoranda bol písaný vo francúzskom jazyku, pričom je možné dohl'adat' jeho nemeckú verziu v štúdii Hermanna Raschhofera. ${ }^{10}$ Ďalšie memorandá preložené do nemeckého jazyka zhromaždil aj Ungarisches Institut München a pre potreby článku sme využili aj preklad uvedený vo Vlastivednom časopise Muzea Hlučínsko. ${ }^{11}$ Memorandum bolo formálne rozdelené na dve časti, prvá sa zaoberala „Vymedzením problému“ a druhá sa týkala „Konečného výsledku“. Prvá čast’ sa členila na tri oblasti- 1. Historické dôvody, 2. Etnografické dôvody, zaoberajúce sa územím l'avého a pravého brehu Odry, 3. Hospodárske dôvody. Súčast’ou memoranda bola aj mapa. V historických dôvodoch sa uvádzali nasledujúce odôvodnenia náležitosti územia: čast' Pruského Sliezska, zasahujúca medzi Tešínsko a Opavsko, bola ako súčast' starého Horného Sliezska, ktoré spolu s Dolným Sliezskom patrili po stáročia k Československému štátu. Od 15. storočia s ním bolo Sliezsko definitívne spojené a vyvinulo sa zo zoskupenia rôznych kniežatstiev v právnu jednotku s pevnou vnútornou organizáciou. Táto rozsiahla oblast', ktorá sa rozprestierala pozdíž rieky Odry až takmer k Frankfurtu nad Odrou, bola po prvýkrát od československého štátu odtrhnutá v roku 1742 Fridrichom Pruským (Fridrich II.). Hoci neexistovali právne dôvody na privlastnenie tejto oblasti, využil Fridrich II. nevýhodnú politickú situáciu českého štátu pri nástupe cisárovnej Márie Terézie na trón. Fridrich II. sa zmocnil Sliezska a udržal si ho. Československému štátu tak zostali len dve malé, od seba úplne oddelené oblasti (Opavské a Tešínske Sliezsko). Po prvotnom vysvetlení, ako sa čast' českého sliezskeho územia dostala v dôsledku Sliezskych vojen pod pruskú nadvládu, sa v memorande zamerali na obhajovanie používania češtiny. Napriek silnej germanizácii,

\footnotetext{
${ }^{7}$ Tamtiež, $101 \mathrm{~s}$.

${ }^{8}$ Memorandá sa zvyknú pripisovat' vtedajšiemu ministrovi zahraničných vecí Edvardovi Benešovi, preto ich je možné označovat' ako Benešove. Memorandá tvoria súbor spisov vytvorených členmi československej vlády na podporu svojich vlastných územných požiadaviek na Parížskej mierovej konferencii.

${ }^{9}$ Pre úplnú správnost' musíme dodat', že územné nároky Československa sa týkali oblasti Ratibořska (ako je d’alej spomenuté aj v názve memoranda) a Hlubčicka.

10 RASCHHOFER, H. : Die tschechoslowakischen Denkschriften für die Friedenskonferenz von Paris 1919/1920. In: Beiträge zum ausländischen öffentlichen Recht und Völkerrecht 24, Berlin. Heymann, 1937

${ }^{11}$ Okrem spomínanej štúdie H. Raschhofera väčšinu memoránd z francúzskeho jazyka do nemeckého bolo preložené aj Ungarisches Institut München. Preklad do českého jazyka Evou Cieślarovou bol uverejnený vo Vlastivědnom časopise Muzea Hlučínska roč. 10, 2020, č.1. ISSN 1804-6967.
} 


\section{PRÁVNE ROZPRAVY ON-SCREEN II. - Sekcia dejín a teórie štátu a práva}

online vedecká konferencia - 13. november 2020

prebiehajúcej v oblastiach Dolného a Stredného Sliezska (s výnimkou oblastí obývaných Poliakmi) a násilnému pruskému režimu zostalo, podl'a autorov memoranda, Horné Sliezsko z národného a duchovného ohl'adu stále v českom vlastníctve. Československo vo svojich súčasných územných nárokoch nežiadalo navrátenie celého územia Sliezska. Požadovalo len čast’ územia Sliezska nevyhnutnej na „Zaoblenie“ svojich hraníc v časti obklopenej českými oblast’ami Opavska a Tešínska. Spomínaná čast' pozostávala z pruského Opavska, časti Ratibořského kniežatstva a panstva Vladislav a Pština.

Druhá oblast' sa zaoberala etnografiou a deklarovala aj štatistické údaje. Lavý breh Odry, resp. pás územia českého Sliezska rozprestierajúca sa od Osoblažského výbežku na juhovýchod až k rieke Odra a prebiehajúceho cez Hlubčice, bol osídlený obyvatel'mi, ktorí boli českého pôvodu a sami sa nazývali „Moravci“. Podstatná čast' obyvatel'stva bola germanizovaná násilím z pruskej strany. Pruský režim podl’a hodnotení autorov memoranda obmedzoval celkový život českého obyvatel'stva. Správa a školstvo bolo nemecké. Napriek všetkému zaznamenávala oficiálna pruská štatistika v roku 191053767 „Moravců““ . Na pravom-východnom brehu Odry sa na základe tvrdení autorov memoranda nachádzalo určité množstvo nepochybne českých obcí. ${ }^{12}$ Pruská štatistika uvádzala všetky tieto obce ako pol’ské. Autori sa snažili odôvodnit' územné nároky aj na základe príbuznosti českého a pol'ského jazyka a používania sliezskeho dialektu, tvoriaceho prechod medzi týmito dvoma jazykmi. Používaný bol vo východnej časti českého Horného Sliezska, pričom jeho obyvatelia sa tiež radili k Poliakom. Sliezsky dialekt obsahujúci prvky českého a pol’ského jazyka sa používal na severe až nad Kozlím (Kędzierzyn-Koźle) a na východe zasahoval až za mesto Pština. ${ }^{13} \mathrm{Na}$ základe vyššie spomínaných dôvodov sa v memorande pokúsili vytýčit' hranice spolu so zakreslením do priloženej mapy. V memorande boli vyslovene vymenované obce, mestá, ktoré by po zakreslení hraníc pripadli Československu. Požiadavkami by Československo dostalo aj vel'ké mestá- Hlubčice, Ratiboř, Rybník, Vladislav, Pštinu. Rozsiahle územné nároky si mohla československá delegácia ospravedlnit’ iba poukázaním na stredoveké české územia a ekonomické záujmy.

Hospodárske dôvody tvorili súčast' memoranda a práve kvôli nim mala Československá republika požadovat’ územie Horného Sliezska. V žiadosti si Československo nárokovalo oblast' Rybnickej pánve, disponujúcou čast'ou uhol’ných ložísk. Dôvodom na

12 Gorschütz (Gorzyce), Olsau (Olza), Odrau (Odra), Bukau (Buków), Grabowka (Grabówka), Lubom (Lubomia), Pogrzebin (Pogrzebień), Wilhelmstal (Kobyla), Markowitz (Markowice), Raschütz (Raszczyce).

${ }^{13}$ Memorandum zur Pariser Friedenkonferenz 1919/1920. Memorandum nr. 8: Das Tschechische Oberrchleisen (Gegend von Ratibor). Čast' etnografické dôvody. 


\section{PRÁVNE ROZPRAVY ON-SCREEN II. - Sekcia dejín a teórie štátu a práva}

online vedecká konferencia - 13. november 2020

uplatňovanie územných nárokov bola okrem iného hospodárska sebestačnost' nového štátu (d’alším z dôvodov bolo možné vyčerpanie zásob uhlia na Ostravsku). V závere memoranda zhrnuli v krátkosti všetky požiadavky, t.j. nárok na oblast' na severe Tešínskeho a Opavského Sliezska, tvoriacu čast' Pruského Horného Sliezska. Československo sa v konečných bodoch memoranda odvolalo na deklarované historické, etnografické a hospodárske dôvody, pričom hospodárske dôvody označilo za najdôležitejšie vzhl'adom na svoju celkovú hospodársku situáciu. Paradaxom ostáva, prečo sa vzhl’adom k dôležitosti hospodárskych a ekonomických dôvodov nevenovali viac tejto problematike, nezapracovali do žiadostí memoranda silnejšiu argumentáciu v prospech získania uhol'ných ložísk, ale do popredia stavali historické dôvody a ochranu moravského etnika.

Po predložení memoránd sa vytýčením hraníc d’alej zaoberala Komisia pre československé záležitosti. Komisia vo svojej správe z marca 1919 odporučila československé požiadavky s tým, že malo dôjst' k výmene území. Za získané časti Kladska a Horného Sliezska na l'avom brehu Odry sa Československá republika mala vzdat' územia na Chebsku. Požiadavka na získanie územia tzv. uhol'nej panvy ned’aleko Ratiboře, na pravom brehu Odry, o ktorého získanie sa Československo usilovalo, bolo zamietnutá. ${ }^{14}$ Správa Komisie bola následne podrobená skúmaniu Najvyššej rady. Nakoniec sa rozhodnutím Vel'kej štvorky zamietla bez skúmania. V priebehu apríla nasledovali d’alšie zmeny hraníc v spojitosti s prerokovaním hraníc s Nemeckom. Výsledkom rokovaní bolo pričlenenie len južných častí pruských okresov- Ratiboř a Hlubčice, čo sa neskôr premietlo do spomínaného čl. 83 Versaillskej zmluvy. Je potrebné zhodnotit', že územné nároky československej delegácie boli neprimerané. Odvolávanie sa na panovanie českých král’ov nad daným územím, spolupatričnost's českou kultúrnou sférou síce boli pravdivé, no do úvahy je potrebné vziat' fakt, že požadované územia boli viac ako sto rokov pod vplyvom Pruska a boli germanizované. Obyvatel'stvo hovorilo českým jazykom, sliezskym dialektom, ale ovládali aj nemecký jazyk, mnohokrát boli s nemeckým etnikom zmiešaný a ich myslenie bolo „pruské““. V memorande sa preto československá delegácia mohla viac zamerat' na získanie požadovaných území argumentáciou postavenou na ekonomických a hospodárskych dôvodov ako na ochranu „Moravcü“, ktorí po rokoch pruského vplyvu možno viac inklinovali k Nemecku, ako k novovzniknutej Československej republike.

\footnotetext{
${ }^{14}$ VÁCHA, Z. : Žádám Vás jako vynikajicího odbornika... Organizace odborných prací pro československou delegaci na mírové konferenci v Pařízi v letech 1918-1919. Masarykův ústav AV ČR, 2013. 162 s.
} 


\section{PRÁVNE ROZPRAVY ON-SCREEN II. - Sekcia dejín a teórie štátu a práva}

online vedecká konferencia - 13. november 2020

\section{Vznik Hlučínska, unifikácia a zákonodarstvo v Hlučínsku}

Južná čast’ okresu Ratibořského sa pričlenila k Československu formálne 30. januára 1920, na základe zákona 76/1920 Sb. o inkorporaci kraje Hlučínského. Názov Hlučínska sa odvodil od najväčšieho mesta v oblasti. Podoba pripojeného územia sa sformovala v čl. 83 Versaillskej zmluvy. K Československu sa od Nemecka nepripojil žiadny historický územný celok, ale len spomínaná južná čast' okresu Ratiboř, predstavujúca 36 obcí a približne 45 tisíc obyvatel'ov. ${ }^{15}$ Rozlohou nadobudnuté územie malo približne $316 \mathrm{~km}^{2} .{ }^{16}$ Severnú hranicu pripojeného územia doslova nakreslil francúzsky generál Henri Le Rond, priložením pravítka na mapu sledovaných oblastí a t’ahom nakreslil priamku vedúcu asi $2 \mathrm{~km}$ južne od Ketře k Bohumínu, k bodu ležiacemu tesne na juh od železničnej trate Ratiboř-Bohumín. ${ }^{17}$ Preto sa zvykne v spojitosti s Hlučínskom hovorit' o umelo vytvorenom regióne. Okrem iného na základe mapky Moravského Ratibořska ${ }^{18}$ (na ktorej bola zakreslená čiara podl’a Versaillskej zmluvy) sa dozvedáme, že tzv. hraničná čiara prechádzala priamo cez územia obcí a nebolo možné určit', či obec patrí ešte do územia Československa. Skutočné pripojenie sa zrealizovalo 4. februára 1920. Štátna hranica, ktorá niekol'ko desiatok rokov viedla korytom rieky Opava, sa posunula na sever. Problém s hraničnou čiarou prechádzajúcou katastrami obcí sa uzavrel v roku 1923, ked' boli k Československu pripojené obce Píšt' a Hat'. ${ }^{19} \mathrm{~V}$ dňoch pripojenia novej oblasti k Československej republike vydali v dobových novinách (Národní listy) tzv. „Proklamáciu k obyvatelstvu Hlučínska“ prezidenta T.G. Masaryka v ktorom sa prehlasuje, že na základe ustanovení Versaillskej mierovej zmluvy a v dohode so všetkými medzinárodnými činitel'mi, počínajúc dnešným dňom (4.2.1920) Československá republika rozširuje svoju suverenitu na vyššie uvedené územia. Tým obyvatelia ( už Hlučínska) nadobúdajú pre seba práva prislúchajúce československým občanom a zároveň na seba preberajú aj povinnosti. Vláda štátu zároveň prejavila očakávania, že nové obyvatel'stvo sa úprimne postaví na stranu nového štátu, že sa lojálne a radi podvolia všetkým jeho opatreniam, ako aj rozhodnutiam všetkých podriadených úradov a orgánov civilným

\footnotetext{
${ }^{15}$ NEMÍNǍ̌, J. : Československé územné nároky v Horním Slezsku. In: Hlučínsko. Vlastivědný časopis múzea Hlučínska. roč. 10, 2020, č.1. 14 s.

${ }^{16}$ BŘESKÝ, A. : Hlučinsko v československém zákonodárství. In: Všenárodní měsíčník NRČ, roč. XV., 1935, s. 1 (ÚK Slezské zemské muzeum Opava).

17 PLAČEK, V. : Prajzáci, aneb K osudiom Hlučínska 1742-1960. Kulturní středisko zámek Kravaře. 2000. 53 s.

18 NEMÍNǍ̌, J. : Hlučinsko slavi narozeniny. In: Hlučínské noviny. Ročník 25, číslo 2, únor 2020. 100 LET VÝROČÍ VZNIKU HLUČÍNSKA, s. 3

${ }^{19}$ NEMÍNǍ̆, J. : Československé územné nároky v Horním Slezsku. In: Hlučínsko. Vlastivědný časopis múzea Hlučínska. roč. 10, 2020, č.1. 14 s.
} 


\section{PRÁVNE ROZPRAVY ON-SCREEN II. - Sekcia dejín a teórie štátu a práva}

online vedecká konferencia - 13. november 2020

a vojenským a sl’ubovala ochranu práva a spravodlivosti ako aj svedomitú starostlivost' o ich blaho. $^{20}$

Dôležitým faktorom, na ktorý je potrebné sa zamerat', je právna úprava na území Hlučínska. Po vzniku Československa bol prijatý recepčný zákon 11/1918 Sb., ktorého výsledkom bol personálny a teritoriálny partikularizmus. Fakticky na území 1. Československej republiky platil najprv právny trializmus. Okrem rozdielov medzi právnymi predpismi platnými v českých krajinách a na Slovensku (a Podkarpatskej Rusi) v zmysle ustanovení zákona č. 76/1920 o inkorporácii Hlučínska k Československu, zostali na jeho území v platnosti dovtedajšie nemecké právne normy. ${ }^{21}$ Právny stav sa dá odvodit' z ustanovenia : „Dosavadní zákony a nařizení, platné v inkorporovaném území, zůstávají v platnosti, pokud je to srovnatelno se změnou suverenity, a pokud nebudou zrušeny nebo změněny zákony a nařizeními republiky Československé.“22 Rozdielna právna úprava sa mala pomaly menit' aj na základe čl. 3, ked’ československé zákony, vyhlásené od 1.5. 1920, mali nadobúdat' platnost' a účinnost' aj na území Hlučínska. Rozdiely medzi platným nemeckým právnym poriadkom, používaným na území Hlučínska, a československým právnym poriadkom sa mali odstránit' vládnymi nariadeniami, pričom zákon 76/1920 Sb. vládu splnomocňoval v tomto zmysle urobit' potrebné opatrenia. ${ }^{23}$ Prechod od stavu trializmu až k stavu dualizmu sa podaril aj na základe nasledujúcich prijatých nariadení, a to 152/1920 Sb., ktorým sa upravuje súdnictvo a rozširuje pôsobnost' zákonov a nariadení z odboru súkromného práva a súdnej správy v územiach postúpenými Československej republike podl’a mierových zmlúv, nariadením vlády 321/1920 Sb. o úprave správy verejnej mimo súdnej správy na Hlučínsku, nariadením 456/1920 Sb. o rozšírení zákonov a nariadení z odboru správy vojenskej na Hlučínsko, nariadením vlády 330/1922 Sb. o rozšírení pôsobnosti z. 98/1874 ř.z. o zakladaní pozemkových kníh, nariadením 168/1921 Sb. o rozšírení platnosti zák. o práve tlačovom a spolkovom na Hlučínsko a d’alšími menej zásadnými nariadeniami.

Pri posudzovaní vplyvu zákonodarstva na územie Hlučínska sme pri svojej štúdii okrem iného vychádzali vo vel'kej miere aj z práce A. Břeského, zaoberajúceho sa v 30 . rokoch 20. storočia Hlučínskom v československom zákonodarstve. Nariadením vlády 321/1920 Sb. o úprave správy verejnej mimo súdnej správy na Hlučínsku boli príslušní

\footnotetext{
${ }^{20}$ Národní listy. č. 34, roč. 60, rok vydania: $1920.4 \mathrm{~s}$.

${ }^{21}$ VOJÁČEK, L.- KOLÁRIK, J.- GÁBRIŠ, T. : Československé právne dejiny (1918-1992). Bratislava: EUROKÓDEX, s.r.o., 2011.31 s.

${ }^{22}$ Čl. 2 zákona č. 76/1920 o inkorporácii Hlučínska k Československu.

${ }^{23}$ Tamtiež, $31 \mathrm{~s}$.
} 


\section{PRÁVNE ROZPRAVY ON-SCREEN II. - Sekcia dejín a teórie štátu a práva}

online vedecká konferencia - 13. november 2020

ministri splnomocnení zariadit', čo bolo potrebné pre vykonanie verejnej správy na danom území, predovšetkým zriadit' úrady, orgány, stanovit' ich sídla, obvody a služobnú podriadenost'. Pre politickú správu bola v Hlučíne zriadená okresná správa politická, ktorá bola podriadená splnomocnenému komisárovi Československej republiky pre Ratibořsko v Opavě a v III. stolici príslušnému ministerstvu. Na základe uvedeného nariadenia vlády bola z hl'adiska starostlivosti o vojnových veteránov (pre presnost' uvádzame pôvodný pojem „,válečných poškozencov“) zriadená okresná úradovňa podliehajúca zemskému úradu pre starostlivost' o válečné poškozence v Brně. „Poškozencum“, ktorým podl’a nemeckých zákonov boli priznané vyššie dôchodky, ako by im prislúchali podl'a československých zákonov, boli ponechané priznané vyššie dôchodky. Komu bol podl'a nemeckých právnych predpisov priznaný menší dôchodok, ako mu prislúchal podl’a československých zákonov, mal priznaný dôchodok podl’a zákonov československých. V nadväznosti na prevod zaopatrenia vojenských ,poškozencov“ na Hlučínsku, bola medzi Československom a Nemeckou ríšou uzatvorená dohoda, vyhlásená v zbierke zákonov a nariadení pod č. 43/1924 Sb. Vládnym nariadením 174/1928 Sb., ktorým sa v zemi Českej a Moravskoslezskej určujú obvody a sídla okresných úradov a niektorých miest so zvláštnym štatútom podrobujú všeobecne platným obecným zriadením boli z okresu Hlučínskeho pripojené k okresu Opavskému obce: Hněvošice, Hoštice Malé a Vel'ké, Chlebičov, Kobeřice, Oldřišov, Rohov, Služovice, Strahovice, Sudice, Třebom a Vrbka. K okresu Hlučínskemu boli pripojené obce okresu Bíloveckého: Děhylov, Dobroslavice, Martinov, Plesná a Třebovice. ${ }^{24}$

Čast' právnej úpravy štátneho občianstva bola upravená aj zmluvou medzi Československou republikou a Nemeckou ríšou, vyhlásenou v zbierke zákonov pod č. 308/1922 Sb. ako zmluva o štátnom občianstve medzi republikou Československou a ríšou Nemeckou. Otázku štátneho občianstva v čl. 84 upravila aj Versaillská zmluva, na základe ktorého štátne občianstvo československé nadobudnú ipso facto príslušníci strácajúci štátne občianstvo nemecké, usadení na niektorom území, známych ako súčast' štátu československého.

V oblasti školstva bola na základe vládneho nariadenia 321/1920 Sb. ustanovená ako vyučovací jazyk čeština. Splnomocnený komisár mohol na žiadost' obyvatel'stva zaviest'

\footnotetext{
${ }^{24}$ BŘESKÝ, A. : Hlučinsko v československém zákonodárství. In: Všenárodní měsíčník NRČ, roč. XV., 1935, s. 1 (ÚK Slezské zemské muzeum Opava).
} 


\section{PRÁVNE ROZPRAVY ON-SCREEN II. - Sekcia dejín a teórie štátu a práva}

online vedecká konferencia - 13. november 2020

nemčinu ako vyučovací predmet na jednotlivých školách. ${ }^{25}$ Komisárovi bola zverená príslušnost' zemskej školnej rady, pričom mohol používat' pre vybavovanie agendy zemské školné rady v Opave. Nemeckí učitelia boli v niektorých prípadoch prevzatí do výučby aj v Československu, ale zväčša boli prepustení zo služby.

Vo finančnej správe boli nariadením zriadené tzv. berní úr̆ad (daňový úrad), berní správa a evidencia katastra pre daň pozemkovú v Hlučíne a na spomínané územie bola rozšírená pôsobnost' finančného inšpektorátu, okresného dôchodkového súdu, finančného inšpektorátu pre trestné dôchodkové veci a poplatkového úradu v Opave. Druhou inštanciou bolo ustanovené finančné riaditel'stvo v Opave. 1. apríla 1920 bola na území Hlučínska zavedená platnost' československých zákonov o priamych daniach s niektorými výnimkami. Zákony nadobudli platnost' aj pokial' išlo o ukladanie prirážok pre samostatné korporácie s odchýlkou, že pre obecné účely sa môžu ukladat' prirážky aj k dani z príjmu. Oprávnenie však bolo r. 1923 zrušené vládnym nariadením. Zákony a predpisy o dovoze, vývoze, prevoze tovaru, colné, monopolné, o kolkoch, štátnej lotérii a dôchodkovom práve trestnom nadobudli účinnost' vo februári 1920. Zákony a predpisy o spotrebných daniach a dávkach, dani obratovej a dani prepychovej, ktoré nadobudli na Hlučínsku účinnost' v r. júli 1920. Vyhláškou ministerstva financií z júla 1920 bol zriadený pre obvod „bernej správy“ v Hlučíne jednotný ukladací okres pre všeobecnú daň z príjmov a „berná komisia“ s ôsmimi členmi. Na ukladanie dane z príjmu bola zriadená odhadná komisia s dvanástimi členmi. ${ }^{26}$

\section{Záver}

Napriek vel'kým očakávaniam československej delegácie na Parížskej mierovej konferencii nedosiahla Československá republika požadované územné nároky. Výsledkom bolo pripojenie len časti územia Horného Sliezska, južnej časti Ratibořského kraja, od r. 1920 nazývanej Hlučínsko. Pripojenie odtrhnutého územia k novému štátu neznamenal koniec teritoriálnych zmien. Na základe Mníchovskej dohody bolo v r. 1938 Hlučínsko pripojené

\footnotetext{
${ }^{25}$ Zriadenie nemeckých škôl v niektorých obciach v Hlučínsku, hoci sa podla zákona mohli zriad’ovat', sa nezrealizovalo z dôvodu neochoty nového štátu. Ked' Československo odmietlo zriadit' menšinové nemecké školy, rodičia boli nepriamo donútení posielat' svoje deti do nemeckých škôl v Opave, resp. platili svojim det’om Privatunterricht, ktorému sa úradníci rovnako snažili zabránit'.

${ }^{26}$ BŘESKÝ, A. : Hlučinsko v československém zákonodárství. In: Všenárodní měsíčník NRČ, roč. XV., 1935. (ÚK Slezské zemské muzeum Opava). $5 \mathrm{~s}$.
} 


\section{PRÁVNE ROZPRAVY ON-SCREEN II. - Sekcia dejín a teórie štátu a práva}

online vedecká konferencia - 13. november 2020

k Nemeckej ríši, ako súčast' Pruského Sliezska. Pripojením k Nemecku a na základe nemeckého štátneho občianstva (ktoré podl'a Nemeckej ríše obyvatelia Hlučínska ani nikdy nestratili) vznikla pre mužských príslušníkov povinnost' narukovat' do Wehrmachtu, čím sa pre obyvatel'stvo Hlučínska začína úplne iná etapa. Poslednou teritoriálnou zmenou v spomínanej oblasti bolo po 2. svetovej vojne znovu pričlenenie k Československému štátu nastol’ujúcou problém začlenenia, označujúceho sa aj ako tzv. Hlučínska otázka.

\section{ZOZNAM BIBLIOGRAFICKÝCH ODKAZOV}

BŘESKÝ, A. : Hlučínsko v československém zákonodárství. In: Všenárodní měsíčník NRČ, roč. XV., 1935. (ÚK Slezské zemské muzeum Opava).

CHODĚJOVSKÝ, J. : Vědci uprostřed "velké politiky": pařǐžská mírová jednání ve svědectví odborných poradců československé delegace. In: DEJMEK, Jindřich. Zrod nové Evropy: Versailles, St-Germain, Trianon a dotváření poválečného mírového systému. Praha: Historický ústav, 2011. s. 145

IRMANOVÁ, E. : Mad’arsko a Trianonská mírová smlouva (pohled českého historika). In: Európa, nemzet, külpolitika, Tanulmányok Ádám Magda 85. születésnapjára. Budapešt’: Aura Kiadó. 2010. ISBN 978-963-7913-38-9, 100 s.

Mírová smlouva mezi mocnostmi spojenými i sdruženými a Německem a Protokol, podepsané ve Versailles dne 28. června 1919, 217/1921 Sb.

Nařízení předsednictva ministerské rady 54/1918 Sb.

Národní listy. č. 34, roč. 60, rok vydania: 1920. ISSN 1214-1240, 4 s.

NEMÍNǍ̌, J. : Československé územné nároky v Horním Slezsku. In: Hlučínsko. Vlastivědný časopis múzea Hlučínska. roč. 10, 2020, č.1. ISSN 1804-6967, 11-14 s.

NEMÍNA ̌̌, J. : Hlučínsko slaví narozeniny. In:Hlučínské noviny. Ročník 25, číslo 2, únor 2020.100 LET VÝROČÍ VZNIKU HLUČÍNSKA, $3 \mathrm{~s}$.

PLAČEK, V. : Prajzáci, aneb K osudům Hlučínska 1742-1960. Kulturní středisko zámek Kravaře. 2000. ISBN 80-902526-5-6, s. 53

RASCHHOFER, H. : Die tschechoslowakischen Denkschriften für die Friedenskonferenz von Paris 1919/1920. In: Beiträge zum ausländischen öffentlichen Recht und Völkerrecht 24, Berlin. Heymann, 1937. 
PRÁVNE ROZPRAVY ON-SCREEN II. - Sekcia dejín a teórie štátu a práva

online vedecká konferencia - 13. november 2020

UNGARISCHES INSTITUT MÜNCHEN: Beneš - Memoranden zur Pariser Friedenkonferenz 1919/1920. Memorandum nr. 8: Das Tschechische Oberschlesien (Gegend von Ratibor) [online]. 2005, [cit. 1. 11. 2020], s. 1-4. Dostupné na internete: http://www.forost.ungarisches-institut.de/pdf/19180000-8.pdf

VÁCHA, Z. : Žádám Vás jako vynikajícího odborníka... Organizace odborných prací pro československou delegaci na mírové konferenci v Paříži v letech 1918-1919. Masarykův ústav AV ČR, 2013. ISBN 978-80-87782-04-0, $162 \mathrm{~s}$.

VOJÁČEK, L.- KOLÁRIK, J.- GÁBRIŠ, T. : Československé právne dejiny (1918-1992).

Bratislava: EUROKÓDEX, s.r.o., 2011. ISBN 978-80-89447-42-8, 31 s.

Zákon č. 76/1920 o inkorporácii Hlučínska k Československu 